\title{
System Modeling of Service Supply Chain in Manufacturing Industry: Using SAP-LAP Hills Framework
}

\author{
Akhilesh Plaiwal* Amaresh Kumar** \\ ${ }^{I}$ M.Tech. Final Year Dept. of Manf. Engg. NIT Jamshedpur-831014 \\ ${ }^{2}$ Assistant Professor Dept. of Manf. Engg. NIT Jamsjedpur-831014
}

\begin{abstract}
The organization can improve their own competency, by applying an appropriate change management scheme. For changing the model of service supply chain, actor-process matrix has been generated by using Situation-Actor-Process (SAP) - Learning-Action-Performance (LAP) model. The case study has been done on "Indo Danish tool room" (IDTR), Jamshedpur. The IDTR has to accepted newer ways of thinking and ideas and also adopted changed environment. Some previous situations of IDTR, has been discussed in this case study. These situations including actors, processes, learning's, actions, and performances have been defined. By analyzing SAP-LAP hills framework technique to find processes which has maximum effort to change management in IDTR. The organization understands from their previous situation and locates excellent key results area in SAP-LAP hills framework. In this way, SAP-LAP has been proved as an ideal tool. The weightage to actor-process matrix is given in range 1-10 and converted to prioritized scores. This will give the location of high and low peaks in SAP-LAP hills framework. The low peaks having greater intensity to change management. It can be recommended to concentrate there and give prime consideration to such situations and how actor needs to behave and how process need to be scheduled under similar situations.
\end{abstract}

Keywords: A SAP-LAP Tool, Flexibility, Situation Analysis, Management Justification, Change Management, Actor-Process Matrix, A Case Study

\section{Introduction}

The aim of case study is to learning issues for each situation and to take out the 'suggested action' for 'improvement in the performance'. In order to deal with the fast changing business reality, flexibility and success of organization so that they not only survive with changing situation but also go on improving their performance by constantly and continuously changing the processes. Organizations have to adopt an appropriate change management for long-term survival and sustainability. Service sectors are getting more and more popularity in the current industrial scenario and service logistics has become a hot topic for discussion also. The qualitative system methodology named SAP-LAP framework gives a glimpse of change management aspects (Husain et. al, 2002). In any industrial environment, situations change very fast. So actor must be flexible enough to change the process and bring out modified services or solutions with new features at competitive rates. Otherwise they will be out of market. The SAP-LAP framework identifies that situation in which there are resources of learning. The role played by various actors in each situation has to be described. The current situation of organization and operating environment also need to be described. In the papers, learning issues in each case have been described, possible actions have been suggested and expected performance has been taken.

\section{Literature Review}

SAP-LAP model has been used by a number of researchers (Kak, 2004; Sushil, 2001b; Husain et al., 2002) in a variety of situations through case studies in automobile and pharmaceutical industry. These case studies have analyzed the issues regarding financial health of companies, core competencies, strategy formulation, and role of flexibility in strategy formulation. Table 1 shows the application of SAP LAP in various industries.

\begin{tabular}{|c|l|l|}
\hline S. NO. & \multicolumn{1}{|c|}{ Authors } & \multicolumn{1}{|c|}{ Remarks } \\
\hline 1. & Sushil (2001) & $\begin{array}{l}\text { Presented mode of inquiry using SAP-LAP } \\
\text { models. }\end{array}$ \\
\hline 2. & Sharma(2001) & $\begin{array}{l}\text { Adoption and operation of flexible manufacturing } \\
\text { technology in Indian context. }\end{array}$ \\
\hline 3. & Majumdar and gupta (2001) & $\begin{array}{l}\text { Examine the initiatives of Indian car manufacturers } \\
\text { in deploying internet and e-business technology } \\
\text { and create internet based business process to gain } \\
\text { competitive advantage. }\end{array}$ \\
\hline 4. & Rawani and Gupta (2001) & $\begin{array}{l}\text { Highlight the learning from strategic information } \\
\text { systems planning in banking sector. }\end{array}$ \\
\hline 5. & Husain et al., (2002) & Analyze technological management practices of \\
\hline
\end{tabular}


System Modeling of Service Supply Chain in Manufacturing Industry: Using SAP-LAP Hills

\begin{tabular}{|c|l|l|}
\hline & & firm in the automobile industry in India. \\
\hline 6. & Kak (2004) & $\begin{array}{l}\text { Learning issues about strategic management, core } \\
\text { competence, ind } \begin{array}{c}\text { flexibility. } \\
\text { insed } \\
\text { pharmaceutical organization. }\end{array}\end{array}$ \\
\hline 7. & Agarwal (2005) & Issues regarding cultural and environmental factor. \\
\hline 8. & Arshinder and deshmukh (2007) & $\begin{array}{l}\text { Analyze a case study of XYZ, a leading } \\
\text { automotive parts manufacturer in India, to throw } \\
\text { light on the status of coordination. }\end{array}$ \\
\hline 9. & Thakkar (2008) & $\begin{array}{l}\text { Information technology adoption } \\
\text { implementation in supply chain. }\end{array}$ \\
\hline 10. & Garg (2009) & Engineering support issues in maintenance. \\
\hline 11. & V.R. Pramod and D.K. Banwet(2010) & $\begin{array}{l}\text { System modeling of telecom service sector supply } \\
\text { chain: a sap-lap analysis. }\end{array}$ \\
\hline
\end{tabular}

Table 1: Applications of SAP-LAP in various industries.

\section{Methodology}

Information of IDTR has been gathered by doing plant training and further discussion with GM and training manager. 10 important situations has been considered for analysis. All situation studied carefully. Wilt the help of above personal the actor and process involved in that situation were identified. Further analysis helped to evolve the learning issues in each situation. The actions decided in view of learning issues. Finally, various performance of the organization is formulated, which are expected outcomes. Using these data an actorprocess matrix has been made. Next step is to quantify them. The response of 10 members ranging from GM to engineer level has been collected. They are requested to mark scale of range 1 to 10 . The sum of score would give a prioritized matrix. Finally SAP-LAP hills framework is prepared.

\section{About The Company}

Indo Danish tool room (IDTR), formally known as central tool room \& training centre, Jamshedpur, is a Government of India society, under ministry of MSME. Tool room has been set-up in year 1991 with assistance of government of Denmark and infrastructure facilities have been provided by state government of Bihar. The total investment in tool room is Rs 60.00 crores.

The main objective is to provide consistent, reliable, quality service for industrial growth based on its trained, skilled and innovative manpower capabilities backed by state of art tool room facilities and provide trained manpower (through long \& short term training).

They undertake design and manufacturing of jigs, fixtures, gauges, die casting dies, press tooling, templates, and plastic moulds etc. for automobile and engineering sectors and machining of precision components with a high accuracy and finish. Along with this they are also conducting 4 year diploma in tool and die making, 2 year ITI, and various short term training courses on CAD/CAM/CAE, CNC, PLC and maintenance etc.

Manufacturing Activities by IDTR:-

- Design and Development of press Tools (cutting and forming).

- Design and Development of moulds (Injection and Compression).

- Design and development of die casting dies (pressure and gravity).

- Design and Development of Gauges.

- Design and Development of fixtures (Inspection \& machining).

- Precision machining of jobs.

- Vacuum heat treatment.

- Component supply of press tooling, die casting and moulds.

- Consultancy for design \& development of new product and cost reduction.

\section{Sap-Lap Framework Formation}

Situations are of fluctuating in nature. Situations always occur sudden in a totally unexpected manner. Depends upon the situation, actor is decided. The situation for different actor can be different. An interplay of situation, actor and process (SAP) leads to learning, action and performance (LAP).

Situations: - All demographics are situations. With each situation, the actor should learn and the action is required to change the process accordingly. This helps to have the best possible outcome or performance. A situation is a function of many internal and external variables. The following situations are considered for study:

1. First situation (S1) -

Installation of big machine tools for large scale production. 
2. Second situation $(\mathbf{S} 2)$ -

Appointment of new employee's as production increases.

3. Third situation (S3) -

Providing training by idtr trainer to company's employee in their company and in idtr plant also.

4. Fourth situation (S4) Experts leaving, IDTR.

5. Fifth situation (S5) -

Increasing the competitor.

6. Sixth situation (S6) -

Starting short term course E-Learning "CATIA".

7. Seventh situation (S7) -

Frequent change in product requirement and variety of product (batch size 250-300 per order).

8. Eight situation (S8) -

Future plan are to become preferred global supplier.

9. Ninth situation (S9) -

Upgrade the short and long term courses.

10. Tenth situation $(\mathbf{S 1 0})$ -

IDTR has to develop faith in mind of training person and customer

Actors:-

The following actor of IDTR have been involved in these situations:

1. General manager (Ar1)

2. Deputy General manager (Ar2)

3. Sr. manager production $(\mathrm{Ar} 3)$

4. Training manager $(\mathrm{Ar} 4)$

5. Technical team (Ar5)

6. Marketing manager (Ar6)

7. Sr. engineer $(\mathrm{Ar} 7)$

8. Design engineer $(\operatorname{Ar} 8)$

9. Faculties $(\operatorname{Ar} 9)$

10. Supplier (Ar10)

Processes:-

The processes which are considered by actors to different-2 situations:

1. Release tender and analysis of technical and commercial data's. (Pr1)

2. Advertise vacancies in internet and popular news papers and in employment news. ( $\operatorname{Pr} 2)$

3. Visiting the companies or industries. (Pr3)

4. Advertise in news papers and websites. $(\operatorname{Pr} 4)$

5. Create more opportunity in field of their expertise. (Pr5)

6. Immediately recruit the expert in same field.(Pr6)

7. To find out strength and weakness of competitor. (Pr7)

8. Prepare video of E-Learning "CATIA" and Acquire web service provider. (Pr8)

9. Opportunity to develop prototype component. (Pr9)

10. Extra effort taken by marketing manager to take review of customer. $(\operatorname{Pr} 10)$

11. Update the courses according to requirement and feedback of industries. (Pr11)

12. Timely provide service with better customer relation and taking new order. $(\operatorname{Pr} 12)$

\section{Learning:-}

Learning issues are framed from the SAP part of study. As the name implies, it is the knowledge gained from SAP part. It is finalized by discussion with general managers and the Training manager. The learning activities in the study are:

1. Knowledge about machine tool and technical specification has to be taken into account. (L1)

2. Machine tool set-up at a proper place. (L2)

3. Examination should have standard level for recruiting suitable employee. (L3)

4. Prepare suitable training package in schedule. (L4)

5. Identification of job opportunity in field of their expertise. (L5)

6. Provide best quality to customer at specied time. (L6)

7. Before starting E-Learning "CATIA", advertise in website of IDTR. (L7)

8. Company has to be good in R\&D and manufacturing capabilities. (L8) 
9. Adoption of new technologies. (L9)

10. Proper knowledge about the course. (L10)

11. More support to supplier and customer. (L11)

Action:-

Action represents the activities to be carried out after learning. It was finalized by discussion with general manager and Training manager. Action phase involves:

1. Hiring a guide who has complete knowledge about machine tool. (a1)

2. Hiring consultancy for selecting suitable candidates. (a2)

3. Acquire suitable trainer to providing training. (a3)

4. Diversification of business. (a4)

5. Taking customer feedback about quality cost and compare with competitor. (a5)

6. Additional effort to satisfy the customer. (a6)

7. Setting-up all machine tool and prototype according to product requirement. (a7)

8. To make contact with many different companies. (a8)

9. Adoption of new technology. (a9)

10. Adoption of modern new software for account and service execution. (a10)

\section{Performance Of The Organization:-}

Performance represents the expected outcome of the analysis. It was finalized by discussion general manager and Training manager. The performance of the organization is multidimensional. Some dimensions and performance of IDTR are:

1. Good customer base. (p1)

2. Increase production with profit. (p2)

3. Recruitment process ending with placement of suitable candidates. (p3)

4. Enhancement of training quality. (p4)

5. Enhancement of business opportunity. (p5)

6. Increase the strength of company. (p6)

7. Saving time of customer and more profitable to IDTR. (p7)

8. Good customer relation. $(\mathrm{p} 8)$

9. Long term and continuous business. (p9)

10. Enhance the knowledge of training employee's and update according to future plan. (p10)

11. Continuous business for a long time. (P11)

\section{Quantified Actor-Process Matrix}

This study includes surveys, interviews, assumptions and judgments by general manager, sr. production engineer, Training manager etc., while quantified output give best judgment by comparison and benchmarking. After the completion of actor-process metrics, the trial for quantification is carried out. It is quantified by giving score for each situation, learning, action and performance. As we have discussed in methodology, the respondents were requested to priorities each situation, learning, action, and performance base on their importance in 1-10 scale based on their importance. They are entered in table: 2 . And finally sum of values are entered in table: 3 .

Table 1: SAP-LAP format of IDTR

\begin{tabular}{|c|c|c|c|c|c|}
\hline Situation & Actor & Process & Learning & Action & Performance \\
\hline $\mathrm{S} 1$ & $\begin{array}{l}\text { Ar3 } \\
\text { Ar5 } \\
\text { Ar7 }\end{array}$ & Pr1 & $\begin{array}{l}\text { L1 } \\
\text { L2 }\end{array}$ & a1 & $\begin{array}{l}\text { P1 } \\
\text { P2 }\end{array}$ \\
\hline $\mathrm{S} 2$ & Ar2 & $\operatorname{Pr} 2$ & L3 & $\mathrm{a} 2$ & P3 \\
\hline S3 & $\begin{array}{l}\mathrm{Ar} 4 \\
\mathrm{Ar} 9\end{array}$ & $\begin{array}{l}\text { Pr3 } \\
\text { Pr4 }\end{array}$ & $\mathrm{L} 4$ & a3 & $\mathrm{P} 4$ \\
\hline S4 & $\begin{array}{l}\text { Ar1 } \\
\text { Ar2 }\end{array}$ & $\begin{array}{l}\text { Pr5 } \\
\text { Pr6 }\end{array}$ & L5 & A4 & P5 \\
\hline S5 & $\begin{array}{l}\text { Ar5 } \\
\text { Ar6 }\end{array}$ & Pr7 & L6 & a5 & P6 \\
\hline S6 & $\begin{array}{l}\mathrm{Ar} 4 \\
\mathrm{Ar} 9\end{array}$ & Pr8 & L7 & a6 & P7 \\
\hline S7 & $\begin{array}{l}\text { Ar6 } \\
\text { Ar7 } \\
\text { Ar8 }\end{array}$ & Pr9 & L8 & a7 & P8 \\
\hline S8 & $\begin{array}{l}\text { Ar1 } \\
\text { Ar6 } \\
\end{array}$ & Pr10 & L9 & a8 & P9 \\
\hline
\end{tabular}


System Modeling of Service Supply Chain in Manufacturing Industry: Using SAP-LAP Hills

\begin{tabular}{|c|c|c|c|c|c|}
\hline & Ar10 & & & & \\
\hline S9 & $\begin{array}{l}\text { Ar7 } \\
\text { Ar9 }\end{array}$ & Pr11 & L10 & a9 & P10 \\
\hline S10 & $\begin{array}{l}\text { Ar6 } \\
\text { Ar9 } \\
\text { Ar10 }\end{array}$ & Pr12 & L11 & a10 & P11 \\
\hline
\end{tabular}

\begin{tabular}{|c|c|c|c|c|c|c|c|c|c|c|c|c|}
\hline $\begin{array}{l}\text { proc } \\
\text { ess }\end{array}$ & $\overrightarrow{\mathrm{E}}$ & ब̊ & $\widehat{\stackrel{m}{E}}$ & 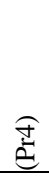 & $\stackrel{n}{e}$ & @ & $\widehat{E}$ & $\stackrel{\widehat{\phi}}{e}$ & $\widehat{\hat{d}}$ & $\stackrel{\widehat{O}}{\vec{E}}$ & $\widehat{\vec{E}}$ & $\frac{\widehat{T}}{\vec{E}}$ \\
\hline$\frac{\bar{g}}{\dot{y}}$ & $\downarrow$ & & & & & & & & & & & \\
\hline Ar1 & & & & & $\begin{array}{l}\mathrm{S} 4=9 \\
\mathrm{~L} 5=8 \\
\mathrm{~A} 4=8 \\
\mathrm{P}=8\end{array}$ & $\begin{array}{l}\mathrm{S} 4=7 \\
\mathrm{~L} 5=8 \\
\mathrm{~A} 4=6 \\
\mathrm{P} 5=7\end{array}$ & & & & $\begin{array}{l}\mathrm{S} 8=9 \\
\mathrm{~L} 9=9 \\
\mathrm{~A} 8=8 \\
\mathrm{P} 9=9\end{array}$ & & \\
\hline $\mathrm{Ar} 2$ & & $\begin{array}{l}\text { S2 }=9 \\
\text { L3 }=8 \\
\text { A2 }=9 \\
\text { P3 }=9\end{array}$ & & & $\begin{array}{l}\text { S4 }=9 \\
\mathrm{~L} 5=8 \\
\mathrm{~A} 4=8 \\
\mathrm{P} 5=8\end{array}$ & $\begin{array}{l}\text { S4 }=7 \\
\text { L5 }=8 \\
\text { A4 }=6 \\
\text { P5 }=7\end{array}$ & & & & & & \\
\hline$\overline{\mathrm{Ar} 3}$ & $\begin{array}{l}\mathrm{S} 1=8 \\
\mathrm{~L} 1=8 \\
\mathrm{~L} 2=6 \\
\mathrm{a} 1=7 \\
\mathrm{p} 1=5 \\
\mathrm{p} 2=7\end{array}$ & & & & & & & & & & & \\
\hline Ar4 & & & $\begin{array}{l}\mathrm{S} 3=9 \\
\mathrm{~L} 4=9 \\
\mathrm{~A} 3=8 \\
\mathrm{P} 4=8\end{array}$ & & & & & $\begin{array}{l}\text { S6 } 6=6 \\
\mathrm{~L} 7=4 \\
\mathrm{~A} 6=5 \\
\mathrm{P} 7=3\end{array}$ & & & & \\
\hline Ar5 & $\begin{array}{l}\mathrm{S} 1=8 \\
\mathrm{~L} 1=8 \\
\mathrm{~L} 2=6 \\
\mathrm{a} 1=7 \\
\mathrm{p} 1=5 \\
\mathrm{p} 2=7\end{array}$ & & & & & & $\begin{array}{l}\mathrm{S} 5=8 \\
\mathrm{~L} 6=9 \\
\mathrm{~A} 5=9 \\
\mathrm{P}=7\end{array}$ & & & & & \\
\hline Ar6 & & & & & & & $\begin{array}{l}\text { S5 }=8 \\
\text { L6=9 } \\
\text { A5 }=9 \\
\text { P6 }=7\end{array}$ & & $\begin{array}{l}\text { S7 }=8 \\
\text { L8 }=9 \\
\text { A7 }=7 \\
\text { P8 }=6\end{array}$ & $\begin{array}{l}\mathrm{S} 8=9 \\
\mathrm{~L} 9=9 \\
\mathrm{~A} 8=8 \\
\mathrm{P}=9\end{array}$ & & $\begin{array}{l}\mathrm{S} 10=9 \\
\mathrm{~L} 11=8 \\
\mathrm{~A} 10=9 \\
\mathrm{P} 11=9\end{array}$ \\
\hline $\mathrm{Ar} 7$ & $\begin{array}{l}\mathrm{S} 1=8 \\
\mathrm{~L} 1=8 \\
\mathrm{~L} 2=6 \\
\mathrm{a} 1=7 \\
\mathrm{p} 1=5 \\
\mathrm{p} 2=7\end{array}$ & & & & & & & & $\begin{array}{l}\mathrm{S7}=8 \\
\mathrm{~L} 8=9 \\
\mathrm{~A} 7=7 \\
\mathrm{P} 8=6\end{array}$ & & $\begin{array}{l}\text { S9= } \\
9 \\
\text { L10 } \\
=9 \\
\text { A9 } \\
=8 \\
\text { P10 } \\
=9\end{array}$ & \\
\hline Ar8 & & & & & & & & & $\begin{array}{l}\mathrm{S} 7=8 \\
\mathrm{~L} 8=9 \\
\mathrm{~A} 7=7 \\
\mathrm{P} 8=6\end{array}$ & & & \\
\hline Ar9 & & & $\begin{array}{l}\text { S3 }=9 \\
\text { L4 }=9 \\
\text { A3 }=8 \\
\text { P4 }=8\end{array}$ & & & & & $\begin{array}{l}\mathrm{S} 6=6 \\
\mathrm{~L} 7=4 \\
\mathrm{~A} 6=5 \\
\mathrm{P} 7=3\end{array}$ & & & $\begin{array}{l}\text { S9= } \\
9 \\
\text { L10 } \\
=9 \\
\text { A9 } \\
=8 \\
\text { P10 } \\
=9\end{array}$ & $\begin{array}{l}\mathrm{S} 10=9 \\
\mathrm{~L} 11=8 \\
\mathrm{~A} 10=9 \\
\mathrm{P} 11=9\end{array}$ \\
\hline $\begin{array}{l}\text { Ar1 } \\
0\end{array}$ & & & & & & & & & & $\begin{array}{l}\text { S8 }=9 \\
\mathrm{~L} 9=9 \\
\mathrm{~A} 8=8 \\
\mathrm{P} 9=9\end{array}$ & & $\begin{array}{l}\text { S10 }=9 \\
\text { L11 }=8 \\
\text { A10 }=9 \\
\text { P11 }=9\end{array}$ \\
\hline
\end{tabular}

Table: 2 Actor-process metrics with the estimated weight-ages. 
Table :3 Quantified actor-process matrix considering weight-ages.

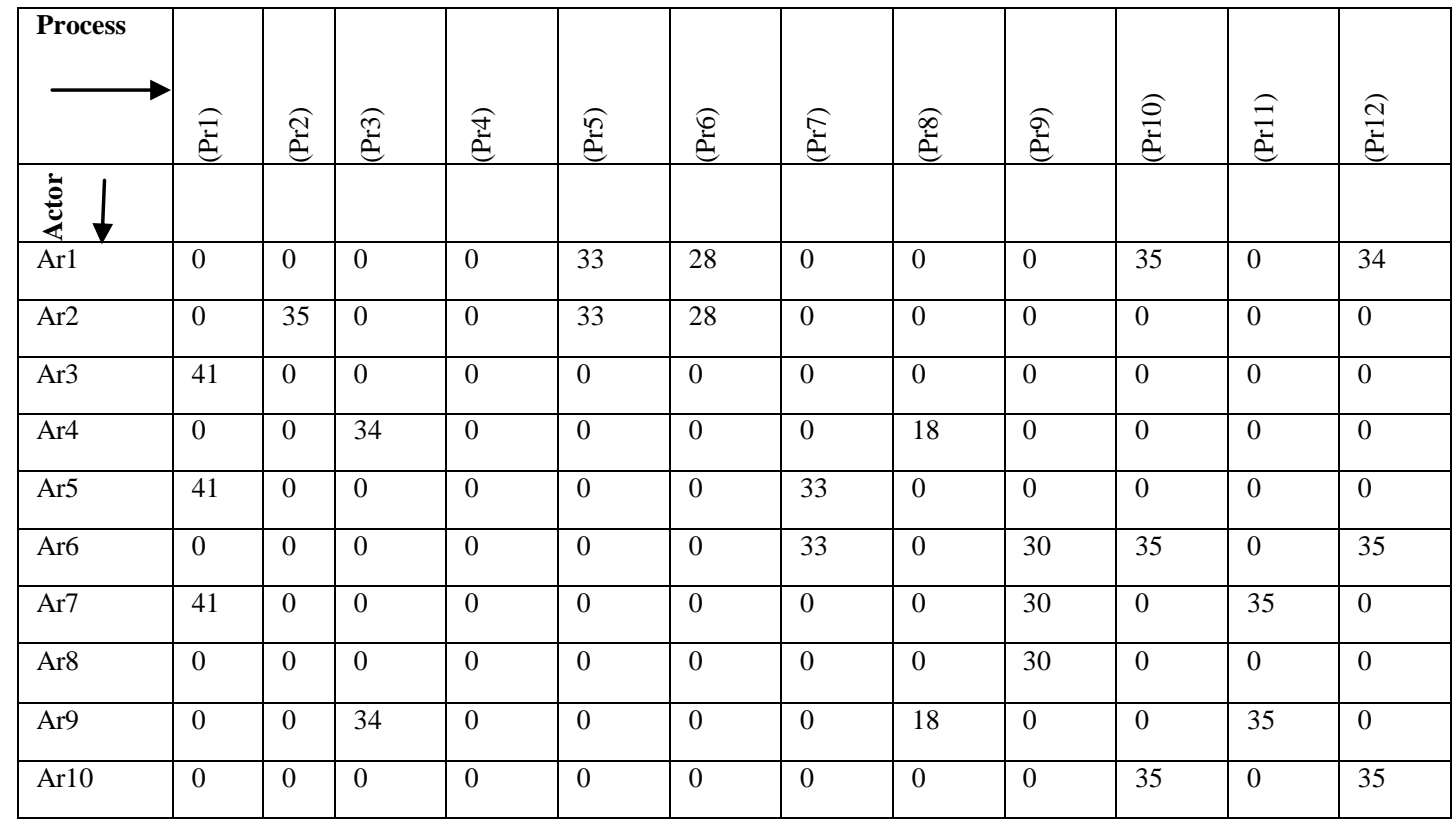

Figure 1: SAP-LAP Hills considering weight-ages.

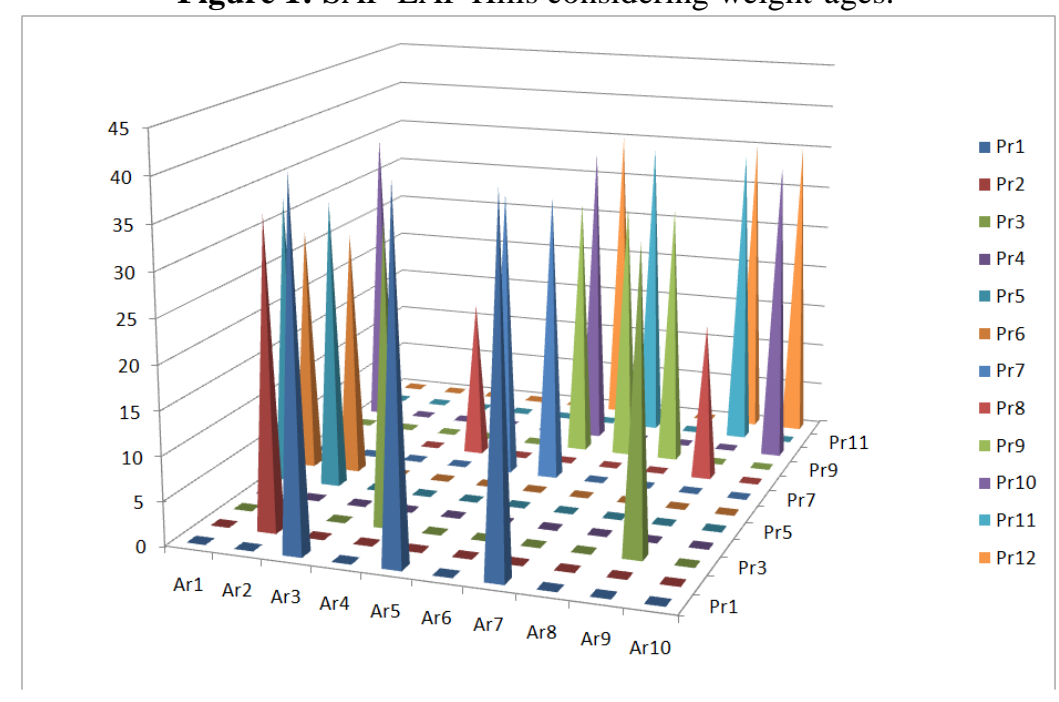

\section{Conclusion And Direction For Future Research}

By means of a structured flexibility analysis named as SAP-LAP, it is possible to recommend an appropriate change management scheme for the entire service supply chain in organization. When we analyze various modes of organizational failures, Current industrialists are giving high importance to change management. SAP-LAP provides a glimpse over various situation, actor and processes and learning, actions, performance. By means of an advanced representation as actor-process matrix, quantification and SAP-LAP hill construction gives the more clear and distinct results. This helped to locate excellent key result areas, Instead of decisions taken by sixth sense and judgments. By observing SAP-LAP Hills framework in figure 1, Low Peaks showing that there is need to change in management while no need to disturb High peaks. For process Pr8, the actors $\operatorname{Ar} 4$ and $\operatorname{Ar} 9$ are not suitable because here score is too low 18 so here need to change in management. The study shows that in order to have a good change management scheme, the organization should concentrate on customer as well as supplier. As a future scope, this "SAP-LAP hills" can be made for other industrial sector. This will help to visualize the key result areas better and investment decision can be made accordingly. This research can be extended by doing case study in different- 2 manufacturing industries that have different size and type of competitiveness. 


\section{References}

[1] Pramod, V.R. and Banwet, D.K., (2010), 'System modelling of telecom service sector supply chain: a SAP-LAP analysis', International Journal of Business excellence Vol. 3, No. 1, pp.38-64.

[2] Senge. M. P, Ross. R, Smith. B, Roberts. C, Kleiner. A (1994), The Fifth Discipline Field book: Strategies and Tools for Building a Learning. Amazon.

[3] Sushil (1997), 'Flexible systems management: an evolving paradigm", Systems Research and Behavioural Science, Vol. 14, No. 4, pp. 259-75.

[4] Sushil (2001), 'SAP LAP Framework', Global Journal of flexible systems management, Vol.2, No.1, pp.51-55.

[5] Agarwal A., "Effectiveness of IT in Supply Chain Performance: A System Dynamics Study", International Journal of Information Systems and Change Management, (2006), Vol. 1, No. 3, 241-261.

[6] Arshinder, Kanda, A. and Deshmukh, S.G. (2004), "C-procurement (Coordinated procurement) in supply chains", Proceedings of the 8th Annual International Conference of the Society of Operations Management, NITIE, Mumbai, India, 17-20 December, pp. 20-37.

[7] Arshinder, Kanda, A. and Deshmukh, S.G. (2006), "A coordination based perspective on the procurement process in supply chain", International Journal of Value Chain Management, Vol. 1 No. 2, pp. 117-38.

[8] Kak, A. (2004), "Strategic management, core competence and flexibility: learning issues for select pharmaceutical organizations", Global Journal of Flexible Systems Management, Vol.5 No. 4, pp. 1-16.

[9] Sushil (2000), "SAP-LAP models of inquiry", Management Decision, Vol. 38 No. 5, pp. 347-53. Sushil (2001a), "SAP-LAP framework', Global Journal of Flexible Systems Management, Vol. 2 No. 1, pp. 51-5.

[10] Sushil (2001b), "SAP-LAP models", Global Journal of Flexible Systems Management, Vol. 2 No. 2 , pp. $55-61$.

[11] Tsay, A. (1999), "The quantity flexibility contract and supplier-customer incentives", Management Science, Vol. 45 No. 10, pp. 1339-58. 